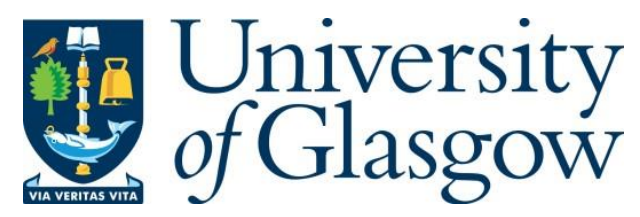

Markovic, A. (2021) Entirely fresh influences in Edwardian Wildeana: queerness in Mary Elizabeth Braddon's The Rose of Life (1905) and Julia Frankau's The Sphinx's Lawyer (1906). Women's Writing, 28(1), pp. 107-122.

There may be differences between this version and the published version. You are advised to consult the publisher's version if you wish to cite from it.

$\underline{\text { http://eprints.gla.ac.uk/197024/ }}$

Deposited on: 16 October 2019

Enlighten - Research publications by members of the University of Glasgow http://eprints.gla.ac.uk 


\title{
Entirely Fresh Influences in Edwardian Wildeana: Queerness in Mary Elizabeth Braddon's The Rose of Life (1905) and Julia Frankau's The Sphinx's Lawyer (1906)
}

\author{
Ana Markovic \\ Department of English Literature, University of Glasgow, Glasgow, UK \\ Ana.Markovic@glasgow.ac.uk
}

\begin{abstract}
Whereas Edwardian male-authored Wildeana tends to represent the Wildean character as a solipsistic bachelor, whose tarnished reputation could affect only his bachelor friends, Mary Elizabeth Braddon's The Rose of Life (1905) and Julia Frankau's The Sphinx's Lawyer (1906) place the Wildean character within the family unit. This allows them to examine the consequences the character's legal prosecution and stigmatisation could have on his wife. Braddon's and Frankau's novels shift the focus from homoeroticism and homosexuality to the catalysing role male influence plays in the development of innate queerness. At the same time, they critically engage with the contemporary belief that female influence might "cure" queerness. Braddon and Frankau avoid demonising and/or oversimplifying the Wildean character's feelings and note that queerness and the family are by no means oppositional or antithetical units. To achieve this effect, they invariably sacrifice women's happiness, which allows us to read their novels as more anti-feminist than anti-queer.
\end{abstract}

Keywords: anti-feminism; Braddon; Frankau; queerness; Wilde; Wildeana

For nearly ten minutes [Dorian] stood there, motionless, with parted lips, and eyes strangely bright. He was dimly conscious that entirely fresh influences were at work within him. Yet they seemed to him to have come really from himself. The few words that Basil's friend had said to him [...] had touched some secret chord that had never been touched before, but that he felt was now vibrating and throbbing to curious pulses. ${ }^{1}$

In this famous scene of corruption from Oscar Wilde's The Picture of Dorian Gray (1891), Dorian stands in ecstasy, enjoying the orgasmic movement of his "secret chord." Lord Henry, whose words have provoked this sensation, stands aside and enjoys the show. Dorian feels as if these influences were not entirely external, as if they had "come really from himself," 
suggesting that what he is feeling has always been within him. A "secret chord" has always been there, waiting for someone's touch. Lord Henry wonders if he has managed to touch it, if the arrow he has shot into the air has "hit the mark." As can be seen from this exchange, in Dorian Gray innate queerness is catalysed by male suggestion and influence. ${ }^{3}$ This theory of influence informs the representations of Wilde's sexual identity in Mary Elizabeth Braddon's The Rose of Life (1905) and Julia Frankau's The Sphinx's Lawyer (1906).

Braddon's and Frankau's novels rely on a complex Wildean nexus to articulate and convey queerness. In these examples of early fictional Wildeana, Wilde and his sexual identity are never explicitly named. Angela Kingston's study of the fictional representations of Wilde in Victorian literature suggests that the "fictional Oscar Wildes are effectively composite creations - part Wilde, part imagination, and part authorial reaction to Wilde." ${ }^{4}$ Her analysis of the representations of Wilde between 1896 and 1900 indicates that in the period following Wilde's trials the authors of Wildeana tended to hint at something corrupt about the Wildean character, but never explicitly reveal the nature of this corruption. Braddon's and Frankau's novels follow these representational trends. In The Rose of Life and The Sphinx's Lawyer, queerness is not a clear, well-defined homosexual identity; it is a vague non-heterosexual identity. The novels combine inborn and acquired interpretations of its development, as they portray queerness as an innate trait whose development depends on suggestion and influence. There are two streams of influence: male influence is almost without exception detrimental, whereas female influence is held out as a possible "cure" for queerness, which almost invariably fails. At the time of his fall from grace, Wilde himself had the reputation of a corrupter of youth. In De Profundis, his 1897 prison letter addressed to Lord Alfred Douglas, Wilde wrote: "[T] he world looks on you as the good young man who was very nearly tempted into wrong-doing by the wicked and immoral artist, but was rescued just in time by his kind and loving father." Constance Wilde, on the other hand, was overtly criticised by Arthur 
Ransome, one of Wilde's early biographers, for not using her influence to save Wilde from corruption. In the first edition of A Critical Study (1912), Ransome claimed that Constance became "more a spectacle for Wilde than an influence upon him, and was without the strength that might have prevented the disasters that were to fall through him on herself."6

The Rose of Life and The Sphinx's Lawyer are critically engaged with the theory of influence and late Victorian writing on homosexuality. Their representations of Wilde' sexual identity reflect both homophobic medical practice and homophile writing. In the late nineteenth century, medical and homophile texts spread the idea that same-sex desire and sexual behaviour could be ascribed to "sexual inversion." This idea originated in the concept of anima muliebris virili corpore inclusa, that is, a female soul in a male body, introduced into homosexual discourse in the late 1860 s by Karl Heinrich Ulrichs. ${ }^{7}$ In the late nineteenth and early twentieth centuries, medical practice sought to reform the so-called inverts by advising them to marry and to reproduce. This approach to inversion was most commonly associated with Dr von Schrenck-Notzing, whose attempts to "cure" inverts relied on hypnotism, alcohol and brothels. ${ }^{8}$ Patients, hypnotised into heterosexuality, less conscious of the gender of their sexual object due to intoxication, and with the help of prostitutes, were supposed to acquire a taste for women. Contemporary homophile writers tried to discredit this reformatory treatment of inverts. Havelock Ellis pointed out that very often the only result of this therapy was a "venereal disorder." As the case studies Ellis published in Studies in the Psychology of Sex; Vol. 2: Sexual Inversion (1898) demonstrate, in the cases of congenital inversion, marriage failed to solve the problem of inversion and caused only depression. ${ }^{10}$ Therefore, homophile writers could see no excuse for forcing male inverts to marry, as this benefited neither men themselves nor women.

Unlike early male-authored Wildeana, such as Saki’s Reginald (1904) or Stephen McKenna's The Reluctant Lover (1912), which allows queerness to thrive in homosocial 
environments and whose protagonists are largely beyond women's influence, the femaleauthored Wildeana analysed in this paper tries to restrain queerness and hinder its development by tying its Wildean characters to women and integrating them into the heteronormative, middle-class family. The Rose of Life and The Sphinx's Lawyer are critically engaged with the contemporary idea that good wives can and should save their husbands from corruption. Unlike homophile writers, Braddon and Frankau view marriage and female influence as a potential solution to innate queerness, although one that rarely proceeds smoothly. They suggest that queer men need not be ostracised, but that through women's unconditional love and selfless devotion they could become loving and loveable husbands. In their novels, the wife is a sacrificial lamb who neglects her own feelings and desires in order to serve her husband, almost as if to prove Lord Henry's argument: "We have emancipated them, but they remain slaves looking for their masters, all the same."11 The Rose of Life and The Sphinx's Lawyer sound almost more anti-feminist than anti-queer. At the time when Suffragettes were fighting for women's rights, Braddon and Frankau published novels in which women are valued only in so far as they might "cure" queerness.

\section{Old-established Twenty Shilling in the Pound Respectability}

In 1905 Christabel Pankhurst and Annie Kenney were arrested for disrupting a meeting of the Liberal Party by demanding voting rights for women. ${ }^{12}$ It was also the year when Mary Elizabeth Braddon (1835-1915) published The Rose of Life, a novel in which an angelic woman saves her husband from infamy through unconditional love and servitude. Perhaps one would have expected to see a different depiction of femininity from a woman whose life, as AnneMarie Beller points out, was truly sensational already in mid-nineteenth century, as

she went on the stage at a time when actresses were seen by many as little better than prostitutes, lived with a man who was already married, bore him six children while serving as stepmother to the five surviving children from his marriage, and secured a reputation as a leading "sensation novelist" whose works were condemned as unhealthy and immoral by conservative critics. ${ }^{13}$ 
Braddon's early novels Lady Audley's Secret (1862) and Aurora Floyd (1863), perhaps her best-known works today, both feature strong female characters who are a far cry from Coventry Patmore's "angel in the house." By the end of her writing career, as Jennifer Carnell observes, Braddon started to sound old-fashioned. ${ }^{14}$ Her reviewers, as well as some women novelists, like Mary Angela Dickens, praised Braddon for her traditional domestic values. ${ }^{15}$ It appears that Braddon came to believe in women's domestic role as caring wives and mothers. However, recent scholarship suggests that even Braddon's earlier works were not unambiguously feminist. In her study of the creative and market impulses that formed the popular image of the "author of Lady Audley's Secret," Kate Mattacks argues that Braddon's works convey her belief in "the socially cohesive nature of domestic, contained femininity." ${ }^{16}$ In The Rose of Life, Braddon's domestic woman serves as a social tool for containing queerness.

The Rose of Life was not the first novel in which Braddon explored queerness. Lady Audley's Secret has been critically scrutinised for signs of homoeroticism and homosexuality. Richard Nemesvari argues that Robert Audley, Lady Audley's nephew, is driven in his detective work by "repressed homoerotic desires" for George, the bosom friend he believes to have been murdered ${ }^{17}$ Furthermore, he suggests that Robert's marriage to George's sister, Clara, at the end of the novel cements the homosocial relationship between Robert and George, and camouflages "its potentially homosexual nature." 18 For Nemesvari, Braddon's description of Robert clearly insinuates queerness. Robert's indifference to his cousin Alicia's affections is repeatedly referred to, thus emphasising its incongruity. We are told: "It might have seemed to other men that the partiality of a young lady, who was sole heiress to a very fine estate, was rather well worth cultivating, but it did not so occur to Robert Audley." ${ }^{19}$ In The Rose of Life, Braddon does not examine queerness in homosocial contexts. The novel focuses instead on the influence a domestic woman can exert over her queer husband. 
The Rose of Life narrates a series of interlinked events which spoil the apparent marital idyll of Braddon's queer Wildean character, Daniel Lester. During one of his walks along the seaside, Daniel is interrupted in his composition of poetry by a young woman, Helen, jumping into the sea. Without thinking, he jumps after her and saves her life. He takes her home to be nursed by his wife Sarah. Determined to provide Helen with a suitable social position, which would free her from the influence of her debauchée mother, Daniel seeks help from his friend Nora, who employs Helen as the governess to her dogs. Here she meets Nora's former lover Malcolm and falls in love with him. Malcolm and Helen marry and, after overcoming a few sensational hurdles - primarily related to Helen's previously unknown bigamy - they find happiness in their marriage. Malcolm's and Helen's bliss enrages Nora, as she is still in love with Malcolm. Curiously enough she does not take revenge on the man she loves, but on her friend Daniel, whom she blames for bringing Helen into their lives. Nora accuses Daniel of financial fraud. Daniel's crime brings to mind Wilde's play An Ideal Husband (1895), that is, Mrs Cheveley's blackmail of Sir Robert Chiltern and his initial determination to protect his wife from the truth. Daniel, in order to spare his wife the scandal of his conviction, commits suicide by drinking poison at his writing desk. Sarah mourns her husband, who is believed to have died of natural causes.

Daniel is Wilde-like in both his temperament and appearance. As Wilde's mother was Braddon's old friend, and Oscar and Constance were regular guests in her family home in the $1880 \mathrm{~s},{ }^{20}$ Braddon knew Wilde well enough to write a faithful portrait of him. Daniel is a brilliant conversationalist, a frivolous and self-centred aesthete, a spendthrift, affected and sentimental, but also generous and kind. His approach to life echoes Lord Henry's philosophy that one should always seek new sensations. Daniel tells his wife that "a poet must know things," he "must feel every beat in the pulse of human life." ${ }^{21}$ Daniel could not be more Wildelike in his looks: 
He was a poet on a grand scale, over six feet three, with wide shoulders, a large head, thick, brown, curling hair, a vast forehead, the brow of a philosopher and a poet, large grey eyes full of power, but the rest of his face was unworthy of the forehead and eyes, for here the second and lower nature of the man expressed itself in the thickness of the nose, the heavy moulding of the lips, the large, loose chin sloping to the large throat. ${ }^{22}$

This emphasis on the contrast between the upper and the lower part of Wilde's face is often found in the descriptions of Wilde by his closest friends. ${ }^{23}$ Robert Sherard wrote that Wilde's facial features which were not "altogether comely" were counterbalanced by the "beauty in the blazing intelligence of his fine eyes." ${ }^{24}$ Lord Douglas said that "nothing would make [Wilde] angrier than the hint that his mouth was too large or that his face was spoiled by too great an expanse of jowl." 25 It appears that Braddon wanted her readers to recognise Wilde in Daniel, suggesting that the purpose of her novel might have been to provoke sympathy for Wilde's suffering.

While Beller claims that in The Rose of Life "there is, of course, no implication of homosexuality,"26 I would argue that Braddon's novel openly describes its Wildean character as a queer man. The narrator states Daniel's sexual identity when we are told that: "To the average man it seemed as if the soul of a pleasure-loving woman were enclosed in that handsome frame; and to such men Daniel counted as a "freak." ${ }^{27}$ In the homosexual discourse of the time, that is, the concept of anima muliebris virili corpore inclusa, this is a straightforward description of Daniel as a sexual “invert.” Braddon portrays Daniel's queerness as an inborn trait rather than an acquired corruption. She never shows her Wildean character exerting influence over other men or being the victim of someone else's influence, nor does she explicitly link his sexual identity to homosexual practices. Furthermore, this part of Daniel's identity is referred to only once in the novel and does not play any role, at least not overtly, in Daniel's fall. Daniel is not guilty of Wilde's crime, "gross indecency," but of financial fraud. By neither accusing Daniel of corrupting youth nor charging him with "gross indecency," Braddon makes it easier for her readers to sympathise with her Wildean character. 
As Beller argues, although we do not know how Braddon felt about Wilde's sexual preferences and his downfall, "the sympathetic treatment of Daniel in her novel would suggest that she did not condemn Wilde, even if she disapproved of his conduct." 28 Moreover, she makes it very difficult not to pity her kind, generous, rather naïve criminal. Daniel's reaction to the charges is almost child-like. When discussing his crime with Oldfield, his lawyer friend, Daniel shows his naïvety, as Oldfield exclaims: "But, my dear fellow, [...] surely you know that forgery is a crime?"29 Braddon seems to imply that Wilde himself was not conscious of the gravity of his actions and the possible consequences for himself and those close to him.

The Rose of Life rewrites not only Wilde's crime, but also his death, making the story of Daniel's fall even more pitiful. Daniel does not die in poverty and exile like Wilde, but instead commits suicide, which Oldfield ensures is presented to the world as a natural death. Braddon creates this alternative scenario that clears Wilde's life of two years of prison with hard labour and an ignominious death in exile through the angelic, never relenting influence of a woman. Daniel's wife Sarah is loving and loyal, forever waiting for her husband to come home. In the narrator's words: "There was a light in the hall; a light that burnt always in readiness for his home-coming - steadfast as the flame in a watch-tower, or a lamp before a shrine." ${ }^{30}$ When we first see her, she is angel-like even in her appearance, wearing a white muslin dressing-gown and her hair framing her head like an aureole. Sarah is "as submissive as an odalisque." ${ }^{31}$ Her absolute annihilation of her own identity in order to serve him leads Daniel to suicide. Rather than tarnish his own and, consequently, her reputation and thus ruin her life, Daniel chooses poison. He wants all the circumstances of his death to be hidden from her and the world so as not harm her: "I would not for the world that my poor Sally should ever know that I deserted her of my own free will; still less would I have her learn the cause. The poor child has made me the god of her idolatry." 32 Braddon's novel thus rewrites the role 
Wilde's wife played in his downfall and offers a grim answer to the question of what would have happened in the 1890s if Wilde had cared more for Constance and her feelings.

Daniel's tragic end shows us that in Braddon's novel powerful female influence has its limitations. Sarah's love does not make her husband any less queer or prevent him from committing a crime, whether it be "gross indecency" or fraud. The Rose of Life suggests that queerness is innate and ineradicable, but that it does not necessarily make queer men unlovable or unloving husbands. However, it appears that the price of restraining queerness is death. Sarah's love and faith in Daniel save him only from infamy. Somewhat ruthlessly, Robert Lee Wolff concludes that, by allowing Daniel to commit suicide, Braddon "may well have been suggesting that this would have been a nobler course for Wilde to follow than to whine about his guilt in Reading Gaol and then to rot helplessly in exile until he died." ${ }^{33}$ We do not know if Braddon wished such an end for her friend. I would argue that, although she wanted to commemorate Wilde and give a sympathetic representation of his queerness and his downfall, Braddon did not want to be accused of immorality.

By charging Daniel with financial fraud, rather than with "gross indecency," and letting him commit suicide, rather than flee or stand the trial and bring shame upon his own and his wife's name, the novel maintains the bourgeois status quo. Just before his suicide, Daniel, usually scornful of Sarah's middle-class family and their bourgeois respectability, tells his wife: "It is their superiority I dread, their substantial, old-established twenty shilling in the pound respectability. That kind of thing is the glory and the strength of England; but it is heavy as lead." 34 Perhaps Braddon's reviewers appreciated this gesture and ignored the Wildean character's sexual identity altogether in their reviews. A reviewer in The Spectator praised Braddon for creating such a life-like character that he almost feels like "a personal acquaintance" and criticised her because she spoilt the reader's pleasure by killing this lovable man. ${ }^{35}$ Braddon's The Rose of Life thus managed to offer a sympathetic account of Wilde's fall 
from grace while maintaining middle-class respectability at the expense of the Wildean character's life.

\section{The Best Is Simple Goodness, Normal Standards, Commonplace}

Like Braddon's The Rose of Life, Frankau's The Sphinx's Lawyer (1906) places the Wildean character within the family unit and examines the role women play in "curing" queerness. Julia Frankau (1859-1916) was a novelist who wrote under the pen name Frank Danby. Today she is known for her representations of Jews and Jewish life in England in Dr Phillips: A Maida Vale Idyll (1887) and Pigs in Clover (1903). In the context of women's studies, she is remembered as an anti-suffrage writer because of her novel Joseph in Jeopardy (1912), in which, according to Jane Eldridge Miller, she "portrayed the suffrage movement as a pernicious enemy of domestic happiness." ${ }^{36}$ Her anti-feminism is clearly visible in her treatment of female characters in The Sphinx's Lawyer, whom she invariably sacrifices to their husbands. Frankau's work is not usually associated with queer studies. She seems not to have been interested in Wilde's sexual identity per se, but in Wilde's life and work in general, and to have written The Sphinx's Lawyer to provoke pity for this friend of her youth.

Frankau was a family friend of the Wildes. She was introduced to Oscar and Willie Wilde by her brother James when he started his newspaper Pan.${ }^{37}$ After their first meeting, Julia's sister tells us, Oscar and Willie paid them regular visits and they all played tennis together, "Oscar in a high hat with his frock-coat tails flying and his long hair waving in the breeze. ${ }^{38}$ Frankau might have been inspired to write the novel by the recent publication of Wilde's De Profundis. The Sphinx's Lawyer opens with a quote from Goethe that Wilde mentions in his prison letter as something his mother used to say whenever she was in difficulty: "Who never ate his bread in sorrow, / Who never spent the midnight hours / Weeping and waiting for the morrow, / He knows you not, ye Heavenly Powers." ${ }^{39}$ Obviously anxious about the reception of her Wildean work, Frankau added a foreword to the novel in which she 
defends herself by stressing that her "hatred of cruelty" should not be "misinterpreted for sympathy with the crime, instead of with the agony, of him who suffered." ${ }^{40}$ Her fear of seeming too sympathetic to Wilde's crime probably made Frankau adopt the homophobic rhetoric of madness and disease when describing her Wildean character's queerness and motivated her detailed examination of the dynamics of positive and negative influence in the development of queerness. This makes her novel not only the most complex and the most direct representation of Wilde's queerness in Edwardian Wildeana, but perhaps also the cruellest.

Ironically, Frankau's novel, which offers a much harsher judgment of the Wildean subject than Braddon's The Rose of Life, was accused of immorality. Frankau, unlike Braddon, overtly stated her intention to provoke sympathy for the suffering of her character in the foreword. Reviewers seem to have understood this as a provocation. A reviewer in The Academy described Frankau's novel as "irredeemably vulgar: vulgar in design, vulgar in execution - it dabbles in depravity with a kind of luscious gusto." ${ }^{41}$ What this reviewer found particularly disturbing was that "through all this unsavoury slush runs a purpose - in such bad taste that it would be incredible if it were not clearly stated in the dedicatory letter - to awaken pity for a man of genius, whose personality is thinly veiled under the name of Algernon Heseltine." 42 Although the character's name recalls the protagonist of Wilde's play The Importance of Being Earnest (1895), the reviewer clearly identified Algernon as Wilde. This review suggests that in the first decade of the twentieth century it was still unacceptable to openly defend Wilde's sexual identity, an ambition which, despite her foreword, Frankau's critics believed she held.

Although the catalyst for the novel's plot, Algernon is not present in the narrative himself. The Sphinx's Lawyer takes place some time after his imprisonment for an unnamed crime and subsequent death. Berenice Darcy, a young and naïve widow, writes to her newly acquired friend, Algernon's wife Mrs Heseltine, to seek her help with legal matters. Sybil 
Heseltine, known to her friends as the Sphinx, is the centre of a hedonist social circle that had first congregated around her husband and after his death continues to gather around her. The Sphinx helps Berenice by sending her Errington, her lawyer and intimate friend. Errington, a well-known womaniser, falls in love with Berenice and her innocence. After overcoming some obstacles, mainly Errington's infidelity and his scandalous championship of Algernon, Berenice and Errington find marital bliss, largely due to Berenice's unconditional love and her faith in his inner goodness. The Sphinx dies regretting that she did not live a commonplace life. She repents and concludes: "The best is simple goodness, normal standards, commonplace." The only comfort she has on her deathbed is the belief that she has eventually saved Kenneth du Gore, a young man she initially planned to ruin, from Algernon's fate.

Even if Frankau had not insinuated in the foreword that the model for her Algernon was Wilde, her readers would have understood this from the text. Algernon came up from Oxford, where he won the Newdigate Prize, just like Wilde. Before his fall, he was admired for his artistic talent and his works enjoyed wide popularity. Among these is a play entitled Lady Chiselmore's Lace Coat, a twist on Wilde's Lady Windermere's Fan (1893). Algernon's controversial work in The Sphinx's Lawyer is "Out of the Depths," in which Algernon writes about his prison life and how "every stone he broke by day became his heart at night.",44 Although the title refers to Wilde's De Profundis, the quote itself comes from The Ballad of Reading Gaol (1897), where Wilde writes: “[E]very stone one lifts by day / Becomes one’s heart by night." ${ }^{, 45}$ Frankau's Algernon is clearly Wilde and, although the crime for which he spends two years in prison remains unnamed, it is probably safe to assume that her readers understood it to be "gross indecency."

Unlike Braddon, Frankau uses the language of disease and madness to describe Algernon's innate queerness. One of Frankau's characters argues that "Heseltine's sanity was more than doubtful. He had, too, an unfortunate family history, and ineradicable hereditary 
predispositions." 46 Algernon's social circle implicitly links Algernon's deviance to the contemporary concept of anima muliebris virili corpore inclusa. Algernon's "disciples" are described as "men of the same tastes, the same perverted instincts, the same desires." 47 A hint that these perverted instincts and desires are related to sexual inversion is found in their poems, such as De Imitatione Hermaphroditi. Unlike Daniel's, Algernon's queerness is not harmless. Frankau's characters suggest that Algernon should "have been placed in safety, kept from spreading his disease, from working evil."48 The social circle in which he spreads his "disease" is a hedonist society governed by the principles of Lord Henry's New Hedonism. "The Master" taught his disciples that "there was neither evil nor good, but only Philistinism or Freedom, from which to choose."49 The novel never reveals what this freedom leads to.

Although she adopts a homophobic rhetoric, Frankau's characters reject homophobic behaviour and criticise society's cruel treatment of queer men. The main homophobe, Berenice's half-brother Harry, is portrayed negatively. He is an uncouth man who does not by any means fit into cultured English society. For Harry, Algernon and his works are "unmentionable. They and he, ought to have been burned by the common hangman." ${ }^{50}$ But not even Harry can name Algernon's crime. When Errington asks him to leave his house, Harry in outrage cries: "You turn me from your house on account of a ..."51 He leaves the sentence incomplete, but this silence must have spoken louder than words to Frankau's readers, as, after all, Wilde's was "the Love that dare not speak its name." 52 The implication is that the cultured English society should be more sympathetic to queer men. Errington argues that it is a disgrace for England to be guilty of "murdering in gaol, along with the lowest malefactors, a poor moral invalid, leper, if you like, but one needing a hospital, not a prison." ${ }^{.53}$ Moreover, Errington underlines that Algernon was ignorant of the gravity of his offence: "He stood before his accusers in the dock, as a child might have stood, impudent, bewildered, irresponsible." 54 Algernon's child-like bewilderment jars with the image of an impudent and irresponsible 
corrupter of youth. In fact, in the whole novel there is a disconcerting clash between sympathy for queer men and harsh homophobic rhetoric. Frankau uses the trope of metalepsis in the depiction of her fallen characters. According to Amanda Anderson, this trope is characteristic of Charles Dickens's writing. Anderson argues that Dickens's depictions of fallen figures oscillate between "victim" and "threat," "effect" and "cause," suggesting thus that these figures are at the same time victims of "a degrading urban milieu" and "a threatening manifestation of those very forces that constituted" them. ${ }^{55}$ Frankau's metalepsis is probably due to her desire to inspire pity for Wilde without defending his actions, as she stated herself in the foreword.

In The Sphinx's Lawyer inborn queerness is triggered by male influence and its development cannot always be inhibited by female influence, at least not by the influence of the Sphinx, Algernon's wife. Unlike Constance and Braddon's Sarah, the Sphinx is not angelic. While the character's first name, Sybil, recalls Sibyl Vane from Dorian Gray, her nickname, the Sphinx, brings to mind Ada Leverson, whom Wilde called "Sphinx," as well as Wilde's poem "The Sphinx" (1894). ${ }^{56}$ The character's corruption and paralysis are references to the poem: Wilde's Sphinx "wake[s] foul dreams of sensual life," as "[i]nviolate and immobile" she watches the narrator through the shifting gloom.${ }^{57}$ Frankau's novel implies that Sybil's love is not pure enough to save her husband from queerness or from infamy. Far from being an angel watching over her husband, Sybil is corrupt herself. She is a hedonist who spends her time indoors, slowly dying of paralysis, amusing herself with her collection of rare books, embroideries and gems, and with dinners organised in Algernon's honour. She belongs to the literary circle of queer hedonists alongside Dorian Gray and Huysmans's Jean des Esseintes. Sybil is said to have been very young "when first she was dazzled by the genius of Algernon Heseltine." ${ }^{58}$ She was a victim of Algernon's influence and eventually she became an "evil" influence herself as a woman who uses her power over men not to save them, but to draw them into her late husband's hedonist circle, possibly even performing the role of homosexual 
procuress. Errington tells us that "[i]t was a quagmire into which she sank, a morass! Through the subtle poison he distilled there was nothing of her but was defiled."59 Once again, Frankau uses metalepsis in her representation of fallenness. She tries to provoke sympathy for Algernon's wife, who "was standing alone to bear a burden that could fit no woman's shoulders, ${ }^{, 60}$ but at the same time she depicts her as a syphilitic corrupter of young men.

The defilement oozing from Algernon that corrupts Sybil is implied to be of a venereal nature, as Sybil's symptoms resemble General Paralysis of the Insane (GPI). GPI manifests itself in the tertiary stage of syphilis as "degenerative dementia" and "developing bodily paralysis." ${ }^{61}$ Sybil passes the last days of her life bedridden after a long illness described as a developing paralysis with frequent attacks, during which she is in too much pain to receive guests. According to Gayle Davis, it was around fin de siècle that syphilis was established as the definitive cause of GPI, ${ }^{62}$ but even decades before this discovery it was associated with "immoral lifestyle." ${ }^{\prime 63}$ Frankau's decision to punish Sybil's immorality with syphilis is not surprising. At the time it was rumoured that Wilde himself had died of syphilis. In the first edition of A Critical Study (1912), Arthur Ransome wrote that Wilde's death was "directly due to meningitis, the legacy of an attack of tertiary syphilis."

Frankau punishes Sybil for her failure to save her husband. The novel makes this clear by contrasting her relationship with Algernon with that of Lilian and Kenneth du Gore. Kenny is one of Sybil's most recent recruits. At the anniversary of Algernon's release from prison, Errington notices: "Six months ago he was a fresh-coloured, apparently ingenious, lad. Now he was haggard, with puffed lids and tremulous hands; it seemed as if corruption had fastened on him." ${ }^{\prime 65}$ Kenny is forced to leave the regiment over an accusation. The content of the accusation is never revealed, but the silence on the matter suggests queerness. During a police raid of a house, probably related to male prostitution, Kenny is nearly arrested. Sybil asks Errington to save Kenny with the help of his wife. She envies Lilian her power to save her 
husband: "This is her great chance, the chance of a life time! [...] If I could have done it, when $m y$ chance came." ${ }^{\prime 66}$ Lilian is tired of Kenny's bullying and wants a divorce. She declares: "I want to be free!" ${ }^{67}$ However, once she realises that Kenny needs her help, she decides to sacrifice her own happiness to save him. The narrator tells us: "There was roused in her by Errington, as he spoke, an inherent womanly longing to be of service." 68 Frankau smothers Lilian's cry for freedom and offers her as a scapegoat to save her husband, in conviction that this selflessness and servitude should be in her womanly nature. Errington and Lilian eventually save Kenny by sending him abroad and later, upon his return, integrating him into Lilian's family again.

Frankau seems determined to prove that every subservient and self-abnegating wife can restrain her husband's queerness within the heteronormative home. Berenice eventually saves Errington from the Heseltines' influence. When thinking about Algernon and his circle, Errington says: "No one knew the influence he wielded, and still wields, better than I do." 69 Berenice's brother tells her that she must use her influence to save her husband. ${ }^{70}$ This is what Berenice does, but subtly, through faith in Errington's inner goodness, her blind trust and unconditional love. Berenice has to learn "to accept suffering from his hands, to see, in humility, her woman's place."71 After a few relapses on Errington's side, Errington and Berenice find happiness and he realises that "[t]he past was dead and must be thrust behind. Before him was happiness and the normal, and so it should be." ${ }^{\prime 72}$ Frankau's women eventually manage to save their men from being led astray. By sacrificing women's happiness, Frankau's novel restrains queerness and maintains middle-class propriety.

The examples of Edwardian female-authored Wildeana analysed in this paper add complexity and nuance to our understanding of Wilde's legacy in the years after his death. Unlike early male-authored Wildeana, which laid the groundwork for the more explicit politicisation of Wilde's sexual identity in the second half of the twentieth century and which 
occupies a clear position in the Wildean continuum, Braddon's and Frankau's novels are unique Wildean texts characteristic of the sociohistorical context in which they were produced. They give us a valuable insight into the position of queerness, that is, Wildean queerness, in Edwardian society. Through their reconciliation of queerness and family life, The Rose of Life and The Sphinx's Lawyer seem to suggest that in the early twentieth century queerness was not invariably ostracised and demonised by heteronormative society. However, in order to maintain heteronormativity, Braddon and Frankau sacrifice women's happiness.

Disclosure statement: No potential conflict of interest was reported by the author.

Word count: 6,988

\footnotetext{
${ }^{1}$ Oscar Wilde, The Picture of Dorian Gray, in The Complete Works of Oscar Wilde (London: Harper Collins, 2003) [1891], 29.

${ }^{2}$ Ibid., 29.

${ }^{3}$ In this paper, I use the term "queer" to refer to a vague non-heterosexual identity. I use the terms "homoerotic" and "homosexual" to refer to same-sex desire and sexual behaviour, respectively.

${ }^{4}$ Angela Kingston, Oscar Wilde as a Character in Victorian Fiction (New York: Palgrave Macmillan, 2007$), 6$.

${ }^{5}$ Oscar Wilde, De Profundis; Epistola: In Carcere et Vinculis, in The Complete Works of Oscar Wilde (London: Harper Collins, 2003) [1897], 1047.

${ }^{6}$ Arthur Ransome, Oscar Wilde: A Critical Study (New York: Mitchell Kennerley, 1912), 81. This passage about Constance, possibly because of its indelicacy, was omitted from the 1913 edition of Ransome's critical study.

${ }^{7}$ Havelock Ellis, Studies in the Psychology of Sex; Vol. 2: Sexual Inversion, 2nd edn (Philadelphia: F. A. Davis Company, 1908) [1898], 230.

${ }^{8}$ Albert von Schrenck-Notzing, Therapeutic Suggestion in Psychopathia Sexualis (London: F. J. Rebman, 1895), 205-9.

${ }^{9}$ Ellis, Studies in the Psychology of Sex, 195.

${ }^{10}$ Ibid., 197-98.

${ }^{11}$ Wilde, Dorian Gray, 82.

${ }^{12}$ On 13 October 1905, Sir Edward Grey came to speak in the Manchester Free Trade Hall. Christabel Pankhurst and Annie Kenney joined the audience and demanded an answer to the question: "Will the Liberal Government give women the vote?" After Grey's speech, as the audience was leaving the hall, Christabel and Annie tried to address the crowd and were consequently arrested. Refusing to pay the fine, they were imprisoned. Emmeline Pankhurst, as a proud mother, concluded: "Christabel is a politician born!" See Sylvia Pankhurst, The Suffrage Movement: An Intimate Account of Persons and Ideals (London: Virago Press Limited, 1977) [1931], 189-92.

${ }^{13}$ Anne-Marie Beller, Mary Elizabeth Braddon: A Companion to the Mystery Fiction (Jefferson, North Carolina, and London: McFarland \& Company, Inc., 2012), 5.

${ }^{14}$ Jennifer Carnell, The Literary Lives of Mary Elizabeth Braddon: A Study of Her Life and Work (Hastings: The Sensation Press, 2000), 281.

${ }^{15}$ Mary Angela Dickens, "Miss Braddon at Home," The Windsor Magazine, June 1897, 415-18.

${ }^{16}$ Kate Mattacks, "Mary Elizabeth Braddon's Secret: An Antifeminist Amongst the New Women," in

Antifeminism and the Victorian Novel: Rereading Nineteenth-Century Women Writers, ed. by Tamara S.

Wagner (Amherst, New York: Cambria Press, 2009), 219 and 230.

17 Richard Nemesvari, "Robert Audley's Secret: Male Homosocial Desire in Lady Audley's Secret," The Novel 27:4 (1995): 516.

18 Ibid., 524.

${ }^{19}$ Mary Elizabeth Braddon, Lady Audley's Secret (London: Tinsley Bros, 1862), 65.

${ }^{20}$ Beller, Mary Elizabeth Braddon, 171.

${ }^{21}$ Mary Elizabeth Braddon, The Rose of Life (Leipzig: Bernhard Tauchnitz, 1905), 151.
} 
${ }^{22}$ Ibid., 9.

${ }^{23}$ As Michèle Mendelssohn observes, in British and American press, the emphasis placed on the thickness of Wilde's lips carried racist implications. In 1881 Punch caricatured Wilde as "a thick-lipped, sunflower-faced Christy minstrel." In 1882, during Wilde's American lecture tour, the press depicted Wilde as "a sunflowerworshipping monkey" and "an aesthetic darkey." Mendelssohn attributes these racist portrayals of Wilde to antiIrish prejudice. See Michèle Mendelssohn, Making Oscar Wilde (Oxford: Oxford University Press, 2018), 56, 91-93, 96-97 and 122 .

${ }^{24}$ Robert H. Sherard, Oscar Wilde: The Story of an Unhappy Friendship (London: Greening \& Co., 1905$), 22$.

${ }^{25}$ Alfred Bruce Douglas, Oscar Wilde and Myself (London: John Long, 1914), 49.

${ }^{26}$ Beller, Mary Elizabeth Braddon, 171.

${ }^{27}$ Braddon, The Rose of Life, 70.

${ }^{28}$ Beller, Mary Elizabeth Braddon, 171.

${ }^{29}$ Braddon, The Rose of Life, 71.

${ }^{30}$ Ibid., 15.

${ }^{31}$ Ibid., 30.

32 Ibid., 107.

${ }^{33}$ Robert Lee Wolff, Sensational Victorian: The Life \& Fiction of Mary Elizabeth Braddon (New York and London: Gardland Publishing, Inc., 1979), 389.

${ }^{34}$ Braddon, The Rose of Life, 82.

35 Anon., "The Rose of Life," The Spectator, May 13, 1905, 717.

${ }^{36}$ According to Jane Eldridge Miller, anti-suffrage fiction is a genre which proliferated in the years preceding the Great War and that depicted the suffragette as an "ugly, sexless and neurotic spinster," reasserting thus "traditional gender definitions, and reassur[ing] the public that the suffragettes were not real women but social misfits mannish, abnormal and obsessed." See Jane Eldridge Miller, Rebel Women: Feminism, Modernism and the Edwardian Novel (Chicago: The University of Chicago Press, 1997), 155-56.

${ }^{37}$ Mrs Aria, My Sentimental Self (London: Chapman \& Hall, Ltd., 1922), 15.

${ }^{38}$ Ibid., 16.

${ }^{39}$ Wilde, De Profundis, 1023.

40 Julia Frankau, The Sphinx's Lawyer (London: William Heinemann, 1906).

${ }^{41}$ Anon., "The Sphinx's Lawyer," The Academy, April 21, 1906, 383.

42 Ibid., 383.

${ }^{43}$ Frankau, The Sphinx's Lawyer, 333.

${ }^{44}$ Ibid., 106.

${ }^{45}$ Oscar Wilde, The Ballad of Reading Gaol, in The Complete Works of Oscar Wilde (London: Harper Collins, 2003) [1897], 898.

${ }^{46}$ Frankau, The Sphinx's Lawyer, 178.

${ }^{47}$ Ibid., 86.

48 Ibid., 108.

49 Ibid., 112.

${ }^{50}$ Ibid., 176.

${ }^{51}$ Ibid., 180.

${ }^{52}$ During his 1895 trials Wilde was asked to explain the meaning of the phrase "the Love that dare not speak its name" which appears at the end of Lord Douglas's poem "Two Loves" (1894). In response to the crossexaminer, Wilde delivered his famous defence of Platonic affection: “"The Love that dare not speak its name' in this century is such a great affection of an elder for a younger man as there was between David and Jonathan, such as Plato made the very basis of his philosophy, and such as you find in the sonnets of Michelangelo and Shakespeare. It is that deep, spiritual affection that is as pure as it is perfect. [...] It is beautiful, it is fine, it is the noblest form of affection. There is nothing unnatural about it. It is intellectual, and it repeatedly exists between an elder and a younger man, when the elder man has intellect, and the younger man has all the joy, hope and glamour of life before him. That it should be so, the world does not understand. The world mocks at it and sometimes puts one in the pillory for it." See Montgomery Hyde, The Trials of Oscar Wilde (London, Edinburgh and Glasgow: William Hodge \& Company, Ltd, 1960) [1948], 236.

${ }^{53}$ Frankau, The Sphinx's Lawyer, 98.

${ }^{54}$ Ibid., 109.

55 Amanda Anderson, Tainted Souls and Painted Faces: The Rhetoric of Fallenness in Victorian Culture (Ithaca and London: Cornell University Press, 1993), 16.

${ }^{56}$ For Leverson's and Wilde's friendship, see Ada Leverson, Letters to the Sphinx from Oscar Wilde; With Reminiscences of the Author (London: Duckworth, 1930). Henry James's novella "The Beast in the Jungle" (1903) also features a sphinx-like female character. James's sphinx, however, is not quite as decadent as Wilde's and Frankau's. See Henry James, "The Beast in the Jungle," in Complete Stories 1898-1910 (New York: Literary 
Classics of the United States, 1996) [1903]. For a queer reading of James's novella, see Eve Kosofsky Sedgwick's chapter "The Beast in the Closet," in Epistemology of the Closet (Berkley, Los Angeles: University of California Press, 1990).

${ }^{57}$ Oscar Wilde, "The Sphinx," in The Complete Works of Oscar Wilde (London: Harper Collins, 2003) [1894], 874 and 882.

${ }^{58}$ Frankau, The Sphinx's Lawyer, 85.

${ }^{59}$ Ibid., 85.

${ }^{60}$ Ibid., 42.

${ }^{61}$ Gayle Davis, “The Cruel Madness of Love: ” Sex, Syphilis and Psychiatry in Scotland, 1880-1930 (Amsterdam - New York: Rodopi, 2008), 15.

62 Ibid., 199.

${ }^{63}$ Ibid., 211.

${ }^{64}$ Ransome, Oscar Wilde, 199.

${ }^{65}$ Frankau, The Sphinx's Lawyer, 113.

${ }^{66}$ Ibid., 193.

${ }^{67}$ Ibid., 243.

${ }^{68}$ Ibid., 249.

${ }^{69}$ Ibid., 81.

${ }^{70}$ Ibid., 231.

${ }^{71}$ Ibid., 67.

72 Ibid., 107. 